\title{
An Example of Decentralized Management in Education: Provincial Directory Model ${ }^{1}$
}

\author{
Sefer Ada ${ }^{1}$, Z. Nurdan Baysal ${ }^{2}$, Senem Seda Şahenk Erkan ${ }^{3}$ \\ ${ }^{1}$ Gedik University, Turkey \\ ${ }^{2}$ Marmara University, Turkey \\ ${ }^{3}$ Marmara University, Turkey \\ Correspondence: Senem Seda Şahenk Erkan, Marmara University, Turkey.
}

Received: August 5, 2016

Accepted: August 22, 2016

Online Published: September 26, 2016

doi:10.11114/jets.v4i10.1785

URL: http://dx.doi.org/10.11114/jets.v4i10.1785

\begin{abstract}
In Turkey, two types of administrative structures existed in the fields of National Education: "the central" and "provincial" institutions. However, between 1926-1931, the Locality model was implemented. Locality can be considered as a local administration formed in the provincial organization of the Ministry of Education by the law number 1834 between the years 1926-1931. Within this arrangement, the provincial structure of Turkey was divided into 13 provincial regions. In every provincial region, there was one administrator called "emin" ${ }^{2}$ " equipped with extensive responsibilities. Then, there was one director of education under the supervision of the emin and other sub-units enabling the implementation of provincial directory. In the "Provincial Directory Model", "The Decentralized Administration" problems could be solved more efficiently, time and resources could be saved by the "Local Directory" within the authorization of emin without consulting the center. Following 1931, this model was rejected without any logical reasons and "the centralized model", which is still being implemented, has emerged. In this model, the expenses of labor, resources and time have been increasing as the problems arising in the province are attempted to be solved in the center.
\end{abstract}

Keywords: Turkey, 1926-1931, decentralization, centralization, provincial management

\section{Introduction}

In Turkey, during the period of 1926-1931, the Provincial Model was implemented by law number 1834. Although this model was implemented only for 5 years, the positive effect of this education management model was extremely high in terms of functional structure. In order to explain the "Provincial Directory Model" clearly, the three basic concepts such as "Centralization", "Decentralization" and "Provincial Directory" should be described in detail. In this model, public administration is divided into two parts namely "Centralization" and "Provincial Directory" in order to ensure that the state and public arrangements are carried out in a continuous way; common goods and services are produced and people are supplied with them in due time (Urhan, 2008). In some countries, the "Mixed Directory" model is mentioned in addition to the above mentioned models. To eliminate the confusion between these two education management concepts, it will be useful to define them separately.

"Central Administration Policy" allows all the legislative judicial and executive powers to be implemented and managed by the "Central Directory" following a chain of command (Köse, 2004). In "Central Administration" the judicial, legislative and executive powers are carried out by ministries and other institutions belonging to them (DBT, 1994, Cited in Özdenkoş, 1999). In brief, state administration consists of two parts: the "Capital" and the "Province". "Local Administration" can be defined as a management, which works independently, whose members are elected by local people in order to understand them and supply them with their needs, whose duties and powers are set by the law. They have their own incomes, budgets and personnel (Urhan, 2008). There must be a balance between sharing services between central and local governments. The reason for the existence of local authorities is to meet the local needs

\footnotetext{
${ }^{1}$ This research is presented as oral presentation in ERPA 2015 International Congresses on Education (4-7 June 2015), in Athens in Greece.

${ }^{2}$ Emin means director.
} 
(Yıldırım, undated, Cited in Özdenkoş 1999). In some studies in the field, the terms "Centralization" and "Decentralization" may cause confusion. The most important difference between "Centralization" and "Decentralization" managements is the extent and transfer of authority. Centralized organizations can decide and carry out their decisions independently and transfer some to the personnel working for them. In the "Decentralized Management", the organizations can decide on some items without asking the central government and implement them (Arslan, 2005). In terms of education the "eminler" are authorized to make the decisions.

The "local authorities" and the "Central government" - giving services together form- a dual management structure and this causes an administrative hierarchy between them. Within this administrative hierarchy the "Central Administration" is superior to the other in terms of authorization. This situation means that the "Centralized Management" can solve the problem of coordination between them (Özdenkoş, 1999).

After briefly explaining Locality, which was applied in Turkey between 1926 and 1931, it is possible to define "Decentralization" as "Locality Management". In this model, some responsibilities of National Education are realized without consulting the provincial education directories. In the applications of this model, the determination, description and resolution of problems are very useful.

\section{Method}

This study is designed in the "Descriptive Scanning Model". Scanning models are approaches of research that describe situations that existed in the past and are still existing (Karasar, 2008), "Descriptive Scanning" is a method that describes the situations from past to the present day with different types of documents such as articles theses and books (King and He, 2005, Cited in Koçak Usluer, Avc1, Kurtoğlu and Uslu, 2013) The "Literature Scanning Method" is a process combining all the knowledge in the books, articles, theses and internet in the field of research (Büyüköztürk, Akgün, Karadeniz, Demirel, 2014, Cited in Şahenk Erkan, 2014).

\section{The First Locality Efforts in Turkey}

In the history of the Republic of Turkey, Provincial Directory Model was applied for the first time, which was inspired by "Decentralized Directory". The Provincial Directories were established during the time when Mustafa Necati was the minister of education according to the $20^{\text {th }}$ and $21^{\text {st }}$ acts of "Educational Directory Law" Number 789, dated March $22^{\text {nd }}$ 1926. The "Provincial Directories Regulations" arranging the working principles of Provincial Directories consisted of 46 items. The education separation of Turkey into regions had been discussed in the year of 1923. Then this separation acted as a base for the construction of "Provincial Directory" of the "Ministry of National Education". The construction of Provincial Directories was made possible with the unification of some cities. A head of educational affairs in smaller units was appointed in charge of education. Primary, secondary and vocational schools were under the control and inspection of these heads and officers. The first meeting was held in Ankara on June $7^{\text {th }}$ and $8^{\text {th }}, 1927$ chaired by Mr. Mustafa Necati, the Minister of national education. The meeting was attended by the personnel in the ministry and also by the Provincial Directories (eminler). The "Decentralization Institution" had its final shape with some changes in the regulations after the meeting in 1927. It was decided that location changes could occur upon the Minister's request. According to the $4^{\text {th }}$ article of the "Regulation of Provincial Directory Model (1926)" the responsibilities of the directors were specified in detail. Related to this article, the duties of provincial directors were as follows (Provincial Directory Regulation, 1926):

-To implement the laws, rules, regulations and orders related to education,

-To identify educational problems and develop solutions for them in their regions,

-To try to provide reading rooms and library facilities,

-To open night and apprenticeship schools,

-To increase the loyalty, the national culture and the idea of democracy,

-To carry out training and educational activities in accordance with the values of the republic,

-To inspect and supervise schools in their area,

-To make statistical arrangements,

-To collect information about cultural, geographical health and economic structure in their own region,

-To appoint primary school principals, headmasters, teachers, primary education and health inspectors, headclerks and clerks; Turkish, Turkish history and geography teachers to work in foreign and minority schools; museum and library officers directly or with recommendations of the director of education,

\footnotetext{
${ }^{3}$ Eminler means directors.
} 
-To make decisions on disciplinary problems in the discipline commission,

-To follow developments related to budgets,

-To send educational reports to the "Ministry of National Education" in their districts in February and July.

Provincial directors were obliged to inspect secondary schools and all educational activities within their vicinity. The Minister of Education had an inspector inspect the provincial directors on considering it to be necessary (Educational Provincial Directors Regulations, 1926). When the Provincial Directory was first constituted, the country was divided into 13 provinces named after the province where it was founded. There were decentralized directories in all the cities belonging to each of these provinces (Bozan, 2004). These provinces were Ankara, İstanbul, Edirne, İzmir, Konya, Sivas, Antalya, Adana, Trabzon, Erzurum, Gaziantep, Van and Elazı ̆․ The following table shows the provinces and the cities operating with them according to a regulation accepted in 1927.

Table 1. Provincial Directory Regions and the cities in 1927

\begin{tabular}{lll}
\hline & Provincial & Cities related to these regions \\
& Directory Regions & \\
\hline $\mathbf{1}$ & Ankara Region & Ankara: Çankırı, Kastamonu, Çorum, Bozok and Kırşehir \\
$\mathbf{2}$ & İstanbul Region & İstanbul: Kocaeli, Bursa, Bolu and Zonguldak \\
$\mathbf{3}$ & İzmir Region & İzmir: Saruhan, Menteşe, Denizli and Karasi \\
$\mathbf{4}$ & Edirne Region & Edirne: Kurklareli, Tekirdağ and Çanakkale \\
$\mathbf{5}$ & Konya Region & Konya: Niğde, Aksaray, Eskişehir, Kütahya and Afyon Karahisar \\
$\mathbf{6}$ & Antalya Region & Antalya: Isparta and Burdur \\
$\mathbf{7}$ & Adana Region & Adana: İçel, Mersin, Çebeli and Bereket \\
$\mathbf{8}$ & Sivas Region & Sivas: Kayseri, Tokat, Amasya, Samsun and Sinop \\
$\mathbf{9}$ & Trabzon Region & Trabzon: Rize, Artvin, Giresun, Ordu and Şarki Karahisar \\
$\mathbf{1 0}$ & Erzurum Region & Erzurum: Erzincan, Gümüşhane, Kars and Beyazıt \\
$\mathbf{1 1}$ & Elazı̆ Region & Elazığ: Diyarbakır and Malatya \\
$\mathbf{1 2}$ & Van Region & Van: Hakkari, Siirt and Bitlis \\
$\mathbf{1 3}$ & Gaziantep Region & Gaziantep: Maraş, Urfa and Mardin \\
\hline
\end{tabular}

Reference: Provincial Directory Regulation, 1926, Cited in Bozan, 2003.

Provincial Directory was abandoned by the law number 183 , dated June $29^{\text {th }}, 1931.123$ people were employed when it was abolished (Yücel,1994). In this law it was clear how much each personnel would be paid in his/her new job. A first class Provincial Director would get 80 TL and a clerk 14 TL.

In order to eliminate the negative impacts of the "Centralized Approach", the "Provincial Directory" created in 1926, could solve the problems more efficiently and on the spot, save time and resources with the authorization given by regulation.

During the period of "Provincial Directory Model" (1926-1931) there were 24.335 primary schools, 387 secondary schools and 99 high schools. The number of schools in total was 24.821 . There were 638.378 primary school students, 110.797 secondary school students and 20.924 high school students. The number of students in total was 770.099 . The total number of teachers was 68.700; 61.416 in primary education, 4354 in secondary school and 2882 in high schools (Çavdar and Düzgüneş, 1973, Cited in Ada, Baysal and Şahenk Erkan, 2015). The number of primary schools decreased only in the academic year of 1928-1929, but increased constantly in the other academic years. The number of secondary schools remained the same between the academic years of 1927-1929, but increased slightly from 1929 to 1931 . The number of high schools was 19 in the first year of Locality education model. But, this number was increased to 22 in the 1930-1931 academic year. As far as the number of students is concerned, it is pointed out that the number of students constantly increased. Besides this, the number of teachers increased in primary and secondary schools whereas this number decreased in high schools only in the academic year of 1928-1929, but increased in the other years (Çavdar and Düzgüneş, 1973, Cited in Ada, Baysal and Şahenk Erkan, 2015). Between the years of 1926-1931 when "Provincial Directory Model" eminle ${ }^{3}$ was applied the total number of students in all stages was 770.099 and the total number of teachers was 68.700. At present, the number of students is over 18 million and the number of teachers is 800.000 . Naturally the number of students and teachers has increased a lot compared to the past. During the period of "Provincial Directory Model", when the aim was to solve the problems on the spot and take over some duties of the central government, it helped to save time and labor. At present the number of students is one and a half times more than the population of 1927, which was 13.562.000 (Çavdar and Düzgüneş, 1973).

Directing so many teachers and students from the center and the ministry making decisions without consulting people in the province who carry on education have made it difficult to diagnose the problems and find solutions for them.

\section{Conclusion}

-In Turkey, where "Centralization" model was applied in terms of state management, "Decentralization (eminlikler $\left.{ }^{3}\right)$ " 
model was adopted in the province only between the years of 1926-1931. The country was divided into 13 main districts. Each district was called by the name of that particular province and some cities were connected to that main district. The number of cities connected was at least 3 (Province of Antalya), and 7 at most (Province of Ankara)

-A provincial Director $\mathrm{emin}^{2}$ was appointed for the management of each province and a Director of Education for each city.

-Provincial Directors were equipped with wide authorization such as recruiting personnel and application of budget.

-As problems were tried to be solved within the framework of authorization transferred by the Central Management, duties were carried out more quickly.

\section{Discussions}

In this research and in Deniz (2016), the researchers studied the Provincial Directory applied from 1926 to 1931 in Turkey. These results are resumed below: "the educational problems existing in one district were resolved in this district with this ancient system." But the consequences are given below (Deniz, 2016): "The Central Education Ministry occupied less educational problems than nowadays, although this ancient system continued only 5 years in 1926-1931 in Turkey."

In this research, the researchers investigated the Provincial Directory applied in 1926-1931 in Turkey. These results are resumed below: "the educational problems existing in one district were resolved in this district with this ancient system." However; Ada, Baysal and Şahenk Erkan (2014) compared this ancient system with the French education Ministries. These consequences are cited below: "The National Education Ministries in France and in Turkey (1926-1931) resolved the educational problems in the district."

In this research, the researchers examined the Provincial Directory applied from 1926 to 1931 in Turkey. These results are resumed below: "the educational problems existing in one district were resolved in this district with this ancient system." However, Yıldırım and Çarıkçı (2013) developed the interview form for investigating the opinions of directors about this ancient system in Turkey. The consequences are enumerated below: "the opinions of directors have differentiated according to their ages and working duration."

\section{Suggestions}

- In the period when "Provincial Directory (eminlikler) Model" was in process (1926-1931), the population of the country was about 14 million, total numbers of schools was 24.821, the number of students was 770.099 and the number of teachers was about 900.000 .

-At present, in spite of the fact that the work load of the Ministry of Education has increased, all the planning and applications are being carried out in the province in accordance as the rules decided in the center caused delays, errors in determining and solving the problems and rising costs in the implementation of duties. In order to eliminate the negative aspects of the central management, it is considered beneficial that the Ministry of Education should transfer some of the duties to the management of provincial education and to the management of smaller units of education in towns in the future.

-It is for sure that the reasons for the problems concerning education in socio-culturally different regions vary. It is not possible to meet the requirements of all cities with standard solutions determined by the center. For this reason, problems can be solved in a shorter time, fewer costs and more accurately by expert staff appointed in each province and city.

-The provincial management of the Ministry of Education follows the rules of the center not only in terms of staff but also in terms of creating budget and spending it. It will be useful to make a legal arrangement to let Provincial and District Managements create their own budget and spend it accordingly.

-One of the most important obstacles to prevent the qualitative and quantitative productivity is the hierarchical order in the "Central Administration". The provincial management is in the position to report its requirements concerning staff and other problems to the "Center" following this hierarchical order. "Provincial Management eminlikler ${ }^{3}$ Model" can be applied in the country in a more modernized way so as to speed up the educational processes at present as well.

\section{References}

2015-2016 National Education Statistics http://sgb.meb.gov.tr/meb_iys_dosyalar/2016_03/18024009_meb_istatistikleri_orgun_egitim_2015_2016.pdf (Retrieved in 03.07.2016).

Ada, S., Baysal, Z. N., \& Şahenk, E. S. S. (2014). Comparaison entre les Applications du Ministère Provincial de la Turquie et les Académies de France (Milli Eğitim Maarif Eminlikleri Uygulamaları ve Fransa).Turkish Studies- 
International Periodical For The Languages, Literature and History of Turkish or Turkic, 9(11), 17-30.

Arslan, N. T. (2005). İdari ve Mali Paylaşım Açısından Merkezi Yönetim Yerel Yönetim İlişkileri. Istanbul University Political Sciences Faculty Journal, No: 33, October 2005, 189-208.

Bozan, M. (2003). Merkeziyetçi Yönetimden Yerinden Yönetime Geçişte Alternatif Yaklaşımlar: Milli Eğitim Bakanlı̆̆ Örneği, Çă̆daş Yerel Yönetimler Journal, January 2003, 12(1), 23-44.

Bozan, M. (2004). Bölge Yönetimi ve Eğitim Bölgeleri Kavramı. Milli Eğitim Journal, 161.

Creswell, J. W. (2009). Research Design: Qualitative, Quantitative, and Mixed Methods Approaches. Sage Publications, England: London, New Age International Press Ltd.

Deniz, M. (2016). Türk Millî Eğitiminde Bir Yerinden Yönetim Örneği: Maarif Eminlikleri. The Journal Academic Social Science, 4(22), 109-117. http://dx.doi.org/10.16992/asos.999.

Karasar, N. (2008). Bilimsel Araştırma Yöntemi (18 ${ }^{\text {th }}$ Edition). Ankara: Nobel Publication.

Köse, Ö. (2004). Yerel Yönetim Olgusu ve Küreselleşme Sürecindeki Yükselişi. Sayıştay Journal, January-March 2004, $52,3-42$.

Kothari, C. R. (2004). Research Methodology -Methods and Techniques (2 ${ }^{\text {nd }}$ Edition). England: London, New Delhi, Age International Press Ltd.

Özdenkoş, D. (1999). Merkezi Yönetim ile Yerel Yönetimler Arasında Görev Bölüşümü. Gazi Üniversitesi İktisadi İdari Bilimler Fakültesi Journal, 2, 77-95.

Polit, D. F., \& Hingler, B. P. (1999). Nursing Research: Principles and Methods (6 ${ }^{\text {th }}$ Edition) USA: Philadelphia, Lippincott.

Provincial Directory Regulation (1926). 29.08.1926 date and Permit No 155/1492.

Toprak, Z. (2013). Türkiye’nin İdari Yapılanmasında Yerel Yönetimler ve Felsefesi. Güncel Sorunlar Işı̆̆ında, Türkiye'de Yerel Yönetimler, Yerel Yönetimler Symposium (21-22 February 2013), Ankara: Yenimahalle Municipality, ODTÜ ve TUİÇ Düzenlemesi.

Urhan, V. F. (2008). Türkiye'de Yerel Yönetimlerin Yeniden Yapılandırılması. Sayıştay Journal, No: 70, 85-102.

Yıldırım, A., \& Çarıkçı, İ. H. (2013). Kamu Örgütlerinde Değişimin Yönetilmesi (652 Sayılı K.H.K. Çerçevesinde MEB Örneği). Mehmet Akif Ersoy University Social Sciences Institute Journal, 5(9), Fall 2013, 106-121.

Yücel, H. A. (1994). Türkiye’de Orta Öğretim. Ankara: T.C. Kültür Bakanlığı Milli Kütüphane Basımevi.

\section{$(c)$ BY}

This work is licensed under a Creative Commons Attribution 3.0 License. 